DOI: http://dx.doi.org/10.18203/2320-1770.ijrcog20175857

Original Research Article

\title{
Need of premarital care
}

\section{Reeta Bansiwal ${ }^{1}$, Pratima Mittal ${ }^{1}$, Jyotsna ${ }^{1}$, Yogita Sharma ${ }^{2 *}$}

\author{
${ }^{1}$ Department of Obstetrics and Gynecology, Safdarjung Hospital, New Delhi, India \\ ${ }^{2}$ Division of Socio-Behavioural and Health Research, Indian Council of Medical Research, New Delhi, India
}

Received: 17 October 2017

Accepted: 17 November 2017

\section{*Correspondence:}

Dr. Yogita Sharma,

E-mail: yogitasharmadelhi@hotmail.com

Copyright: ( ) the author(s), publisher and licensee Medip Academy. This is an open-access article distributed under the terms of the Creative Commons Attribution Non-Commercial License, which permits unrestricted non-commercial use, distribution, and reproduction in any medium, provided the original work is properly cited.

\begin{abstract}
Background: Marriage is considered a remarkable event in an individual's life. It provides people with a sense of belonging, support, security and responsibility. We put so much of efforts to find a good match for our younger and loved ones but we forget to match the most important wealth of our life "Health". This study aimed to know the knowledge, attitude and practice of the population through a structured questionnaire.

Methods: A cross-sectional study was conducted using a self-administered questionnaire which was distributed to 110 males and 110 females attending Medicine and Gynae OPD at Safdarjung hospital, New Delhi. Participants were questioned according to the self administered questionnaire and their answers were evaluated.

Results: Only $11 \%$ of males new of premarital counseling and none of the females were aware of premarital care. Contraception knowledge was also poor among females as 7\% females new only I-Pill as the method of contraception. After knowing the importance of premarital counseling and screening $92 \%$ males and $52 \%$ females agreed for premarital counseling and screening.

Conclusions: Marriage provides people with a sense of belonging, support, security and responsibility. Premarital care nurtures it and fill its "Neev" with the goodness of health. Therefore, it is recommended that premarital care is important before every marriage for the happy and healthy family ahead.
\end{abstract}

Keywords: Attitude, Knowledge, Contraception, Practice, Premarital care (PMC)

\section{INTRODUCTION}

Premarital counselling is a way to help couples to prepare for marriage. It identifies and modifies the behavioural, medical and other health risk factors through prevention and management. Husband and wife are the foundation of family and their sound health is very important for strong and healthy family and the future progeny. According to study at JIPMER, Pondicherry STD's are on the rise due to marital contact. ${ }^{1}$ Worldwide 7.9 million births occur annually with serious birth defects and $94 \%$ of these births occur in the middle and low income countries. ${ }^{2}$

Premarital counselling is the key to reduce all these problems. However, very few facilities in our country are providing these services and still, this concept is not popular in India. To find out the lacunae this study was planned and conducted to know the knowledge, attitude and practice of the population through a structured questionnaire and to know the feasibility of delivering such counselling among people.

\section{METHODS}

This was a cross sectional study conducted from December 2015 to January 2016 in the department of Obstetrics and Gynecology, VMMC and Safdarjung hospital, New Delhi which is a tertiary care hospital and caters to the population of Delhi and referrals from surrounding states (Haryana and Uttar Pradesh). 
Males and females of the age 25 to $35 y$ rs coming to the Medicine and Gynae OPD's were recruited in the study and after informed consent, they were subjected to questions according to the structured questionnaire and their responses were noted. The sample size has been estimated using the formula, $n=4 \mathrm{PQ} / \mathrm{L} 2$ where $\mathrm{p}$ was taken as 50 as no previous such studies found and $\mathrm{L}$ the allowable error was taken as $6 \%$ it was estimated that at least 277 subjects will be required. Therefore, the target was set to reach 280 participants in order to achieve the objective of the study with equal ratio of males and females. A total of 280 persons were approached and 246 consented to participate in the study. Nonetheless, 26 questionnaires were excluded from the study due to incomplete responses. A total of 220 subjects were therefore included in the analysis.

Based on available literature on Knowledge Attitude Practice (KAP) paradigm on premarital care (PMC), a questionnaire was developed in English as well as in local language Hindi. The questionnaire included both close- and open-ended questions. Close-ended questions, in a checklist format, were designed to investigate people's knowledge towards PMC. The questionnaire was composed of four main parts: socio-demographic data, questions to assess subjects knowledge, attitude and practice on premarital need of counseling, screening tests, impact of addictions on family and future progeny. Structured questionnaire was used to collect the data under the supervision of qualified nurses and health educators and their answers were evaluated. Candidates who agreed to participate in the study were asked to sign a consent form, and were provided with contact details of the investigators for any further inquiries. All potential participants received an information sheet that covers all aspects of the study, and their inquiries were responded to. Participants were questioned according to the structured questionnaire and their answers were evaluated.

\section{RESULTS}

From Table 1 it can be seen that the study population consisted of males and females of compared age.

Table 1: Demographic profile.

\begin{tabular}{|lll|}
\hline Age & Males & Females \\
\hline $\begin{array}{l}\text { Education } \\
\text { Illiterate }\end{array}$ & 26 yrs & 24 yrs \\
\hline $\begin{array}{l}\text { graduate } \\
\text { Marital Status }\end{array}$ & $64 \%$ & $48 \%$ \\
\hline married & $36 \%$ & $52 \%$ \\
\hline Unmarried & $34 \%$ & $66 \%$ \\
\hline Religion & $66 \%$ & $34 \%$ \\
\hline Hindu & & \\
\hline Muslim & $80 \%$ & $94 \%$ \\
\hline Christian & $20 \%$ & $4 \%$ \\
\hline
\end{tabular}

Females had higher literacy rate as compare to males. Maximum people were of Hindu religion and belonged to lower class and lower middle class.

\section{Knowledge}

Surprising results came when their knowledge was assessed.

Table 2: Knowledge.

\begin{tabular}{|c|c|c|}
\hline & Males & Females \\
\hline Premarital counseling & $11 \%$ & \\
\hline Legal age of marriage & $88 \%$ & $81 \%$ \\
\hline Ideal age of marriage & $25 y r s$ & $22 \mathrm{yrs}$ \\
\hline Ideal age of having first baby & $26 y r s$ & $23 y r s$ \\
\hline Herediatary disesses & $2 \%$ & $1 \%$ \\
\hline $\begin{array}{l}\text { Transmission of disease through } \\
\text { marriage }\end{array}$ & $17 \%$ & $26 \%$ \\
\hline Psychological burden & $28 \%$ & $27 \%$ \\
\hline Monetary burden & $31 \%$ & $27 \%$ \\
\hline $\begin{array}{l}\text { Screening of couple help future } \\
\text { baby }\end{array}$ & $25 \%$ & $16 \%$ \\
\hline $\begin{array}{l}\text { Health status of patterns impact } \\
\text { on future baby }\end{array}$ & $100 \%$ & $39 \%$ \\
\hline
\end{tabular}

Table 2 shows only $11 \%$ of males had ever heard of premarital counseling through internet and none of females knew about it. $80 \%$ of females as well as males knew about right age of marriage and first child bearing. Only 1-2 \% of people knew of hereditary diseases and among them only 20-30 \% believed that it has a psychological, biological and monetary impact over the family and future progeny.

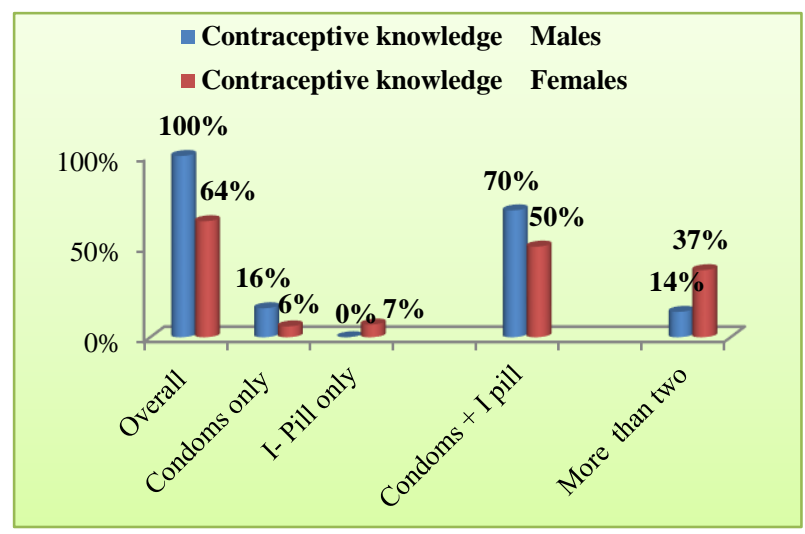

Figure 1: Knowledge of contraception among participants.

As far as contraception was concerned $100 \%$ males knew of some sort of contraception but $70 \%$ knew only about condoms and I- pill as a contraception and only 14 $\%$ knew more than 2 means of contraception.

Overall only $64 \%$ females knew of contraception and surprisingly $7 \%$ of the female knew I -Pill as a 
contraception, which is actually an emergency contraception (Figure 1).

$80 \%$ of males and $20 \%$ females were addicted to some sort of substance (alcohol, cigarette, tobacco) and the impact of substance abuse was known to only $36 \%$ of males and none of the females were aware of it (Figure 2).

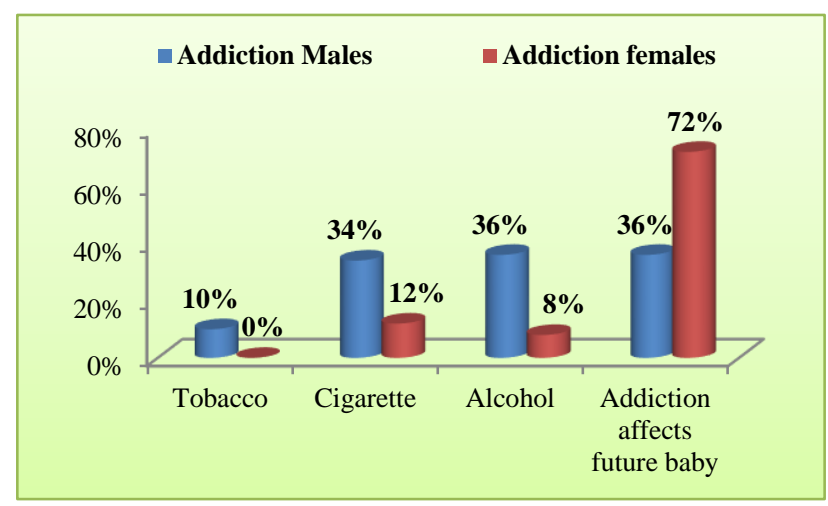

Figure 2: Addiction among participants.

\section{Attitude}

After knowing the importance of premarital counselling and screening $92 \%$ males and $52 \%$ females irrespective of their marital status had the same attitude and were keen for premarital counselling and screening.

80-100\% males will opt moving out of relationship if found before marriage whereas $40-50 \%$ of females had the same attitude and wanted their partners to be diseased free and were willing to opt out of marriage (Table 3 ).

\section{Table 3: Attitude.}

\begin{tabular}{|c|c|c|}
\hline & Male & Female \\
\hline Premarital counselling & $92 \%$ & $52 \%$ \\
\hline \multicolumn{3}{|c|}{$\begin{array}{l}\text { If partner has following disease, how many opted to } \\
\text { walk out of relationship. }\end{array}$} \\
\hline DM & $86 \%$ & $44 \%$ \\
\hline HTN & $92 \%$ & $42 \%$ \\
\hline Mental illness & $100 \%$ & $57 \%$ \\
\hline Kidney diseases & $100 \%$ & $57 \%$ \\
\hline HIV & $100 \%$ & $54 \%$ \\
\hline Hereditary diseases & $100 \%$ & $99 \%$ \\
\hline $\begin{array}{l}\text { Agree to Consanguineous } \\
\text { Marriage }\end{array}$ & $20 \%$ & $18 \%$ \\
\hline Plan pregnancy & $80 \%$ & $58 \%$ \\
\hline
\end{tabular}

Inspite of awareness about problems in consanguineous marriage $20 \%$ males and $18 \%$ females were willing for the same due to familial, cultural and religious belief.

It was heartening to see that $80 \%$ of males and $58 \%$ of females wanted to plan the pregnancy provided they know how to do that (Table 3).

\section{Practice}

In majority of the cases, it was the elders in the family who arrange marriage and 40-50\% believe in kundali match or horoscope. Only $10-20 \%$ do screening tests to know health status and surprisingly $10-20 \%$ has no idea and they believe in destiny and fate (Table 4).

Table 4: Practice.

\begin{tabular}{|lcl|}
\hline How they choose their partner & Males & Females \\
\hline Arrange mariage & $96 \%$ & $64 \%$ \\
\hline Do they talk before marriage & $90 \%$ & $92 \%$ \\
\hline $\begin{array}{l}\text { Kundali match } \\
\text { Anybody in family gone for }\end{array}$ & $50 \%$ & $48 \%$ \\
\hline $\begin{array}{l}\text { premarital clinic } \\
\text { How to know their partners heath status }\end{array}$ & $0 \%$ & $0 \%$ \\
\hline $\begin{array}{l}\text { Medical tests } \\
\text { No idea }\end{array}$ & $22 \%$ & $6 \%$ \\
\hline
\end{tabular}

As already guessed none of them ever went for premarital counselling before marriage.

\section{DISCUSSION}

Premarital care (PMC) is the promotion of the health and well-being of a woman and her partner before marriage. It seems to be very promising in decreasing the burden of hereditary diseases, STD's, birth defects, divorce rates. Due to the benefits of PMC, this study was designed to elicit people's knowledge, attitude, and practice towards $\mathrm{PMC}$ in a public sector.

In Egypt, the first premarital care started since mid-2001. Nowadays, PMC became compulsory by law in many Arab countries including Egypt (UNFPA, 2010). But still in many countries people are reluctant to go for such counseling and screening tests, moreover clinics of such kind are also less and mainly present in private sectors. In our study large gaps found in the knowledge of even literate people. Only $11 \%$ of males have heard of premarital care that to through internet and friends and not through health professionals. This finding was in accordance with Azeem et al who did an interventional educational prospective study to assess and improve knowledge and attitude of 200 medical students in Fayoum University towards premarital care services and found mass media (T.V) as main source of information $(65.5 \%) .{ }^{3}$ Baron-Epel also found media and friends, not health professionals as the primary sources of information for young women and men of all ages; Bastani et al also found similar findings as in our study that many young women and men enter into marriage with insufficient information on sexuality, reproduction, and family planning. ${ }^{4,5}$ hence, inadequate information is expected in youngsters. Knowledge of hereditary diseases and their impact on their lives was also less, in our study (1-2\%). 
$80 \%$ of females as well as males knew about right age of marriage and first child bearing in present study but still according to 2011 census of India $33 \%$ of women marry before 18 in India and $18 \%$ of maternal deaths occurred in this age group due to pregnancy related complications. This is widely known that adolescent pregnancy remains a major contributor to maternal and child mortality and to the ill cycle of ill health and poverty. These figures make us rethink, where is the lacking, is it knowledge, awareness, health system or education? Main problem of India is its large population and preventing unintended pregnancy through contraceptive knowledge is the way to overcome the problem of population explosion. Present study found that among males and females, $100 \%$ of males knew of atleast some sort of contraception but females were found ignorant. Overall only $64 \%$ females knew of contraception and surprisingly $7 \%$ of the female knew only I -Pill as a contraception, which is actually an emergency contraception and fails to protect if taken multiple times in the same cycle. This was also seen in the Bansiwal et al where 150 women were interviewed and found that $80 \%$ of women had some or the other knowledge of contraception but still $92(61.3 \%)$ were not using any contraception, $54(36 \%)$ were using barrier method and only 4 (2.6\%) were using OCP's. ${ }^{6}$ Jayshree J et al also found in their study that $92.5 \%$ of women were aware of one or other method of contraception. ${ }^{7}$ But only $42.5 \%$ were practicing contraception. Lack of awareness and ignorance are the main culprit in the society for which adolescent and premarital counseling are very promising.

After knowing the importance of premarital counseling and screening $92 \%$ males and 52\% females agreed for premarital counseling and screening in our study and $80 \%$ of males and $58 \%$ of females wanted to plan the pregnancy. This showed social stigma or familial pressure also has a bearing on planning and limiting the family size, but literacy and knowledge find its own way to overcome this problem. This was in accordance with different studies conducted on divergent participants as health care providers where health education intervention applied succeeded in improving the knowledge significantly affirming that it is the corner stone in promotion of Premarital care. ${ }^{8-13}$ Elders takes so much of pain in finding the good match for their dear ones by inquiring and kundali match but forget to match the health kundali and find a biological compatible match which ensures not only a healthy family but also lead to a healthy progeny ahead. People fear getting ostracized or not being able to get a partner if they declare even the most minor health problem which is also shown in our study. They have to understand the fact that it's better to know your problems before then to seek for help afterwards. Problems can be identified, rectified or optimized before they start their family so that they don't interfere with the pleasure of married life and leads to healthy family and progeny ahead. People have to understand the idea behind and the benefits of Premarital care.

\section{CONCLUSION}

Marriage provides people with a sense of belonging, support, security and responsibility. Premarital care nurtures it and fill its "Neev" with the goodness of health. Therefore, it is recommended that premarital care is important before every marriage for the happy and healthy family ahead.

\section{Funding: No funding sources Conflict of interest: None declared \\ Ethical approval: The study was approved by the Institutional Ethics Committee}

\section{REFERENCES}

1. Thappa DM, Kaimal S. Sexually transmitted infections in India: Current status (except human immunodeficiency virus/acquired immunodeficiency syndrome. Available at http://www.eijd.org/article.asp?issn=00195154;year= 2007; volume $=52 ;$ issue $=2$; spage $=78$; epage $=82$.

2. Christianson A, Howson CP, Modell B. March of Dimes (MOD). Global Report on Birth Defects. Available at https://www.marchofdimes.org/globalreport-on-birth-defects-the-hidden-toll-of-dying-anddisabled-children-full-report.pdf

3. Al Azeem ST, Elsayed ET, El Sherbiny NA. Promotion of knowledge and attitude towards premarital care: An interventional study among medical student in Fayoum University. J Public Health Epidemiol. 2011 Mar 31;3(3):121-8.

4. Baron-Epel O. Consumer-oriented evaluation of health education services. Patient Educ Couns J. 2003;139:47-9.

5. Bastani F, Hashemi S, Bastani N Haghani H. Impact of preconception health education on health locus of control and self-efficacy in women. East Mediterr Health J. 2010;16(4):11-17.

6. Bansiwal R, Singh P, Bajpai S. Practice of contraception in this modern world: still a myth? Int J Reprod Contracept Obstet Gynecol. 2015;4(3):6747.

7. Upadhye JJ, Upadhye JV. Contraceptive awareness and practices in women of urban India. Int J Reprod Contracept Obstet Gynecol. 2017 Apr;6(4):12791282.

8. Sanghvi T, Merkatz IR, Bernstein P. Improving preconception care. J Reprod Med. 2000;45(7):546552.

9. Chen B, Lu YN, Wang HX, Ma QL, Zhao XM, Guo $\mathrm{JH}$ et al. Sexual and reproductive health service needs of university/college students: updates from a survey in Shanghai, China. Asian J Androl. 2008;4:607-15.

10. Mevsim V, Guldal D, Gunvar T, Saygin O, Kuruoglu E. Young people benefit from comprehensive education on reproductive health. Eur J Contracept Reprod Health Care. 2009;14(2):144-52. 
11. Sobhy SI, Shoeib FM, Zaki NH. Assessment and upgrading of Alexandria University nursing students' knowledge and attitudes about genetic counseling. J Egypt Public Health Assoc. 2001;76(3-4):205-222.

12. Elsinga J, Jong-Potjer LC, Pal-de Bruin KM, Cessie $\mathrm{S}$, Assendelft WJJ, Buitendijk S. The effect preconception counselling on life style and on the behaviour before and during pregnancy. Women's Health Iss. 2008;18:117-125.

13. Rao RSP, Lena A, Nair S, Kamath V, Kama A. The effectiveness of reproductive health education among adolescent girls: A school based intervention study in Udupi Taluk, Karnataka. Indian J Med Sci. 2008;62(11):439-43.

Cite this article as: Bansiwal $\mathrm{R}$, Mittal $\mathrm{P}$, Jyotsna, Sharma Y. Need of premarital care. Int J Reprod Contracept Obstet Gynecol 2018;7:257-61. 